JAN ILUK

University of Silesia, Katowice

jan.iluk@us.edu.pl

MARIUSZ JAKOSZ

University of Silesia, Katowice

mariuszjakosz@interia.pl

\title{
STORYTELLING AND ITS EFFECTIVENESS IN DEVELOPING RECEPTIVE SKILLS AMONG CHILDREN
}

Keywords: storytelling, affectivity, receptive skills, verbal behaviour, lexical item

\begin{abstract}
The study was conducted at the University of Silesia within the group of approximately 100 children from three kindergartens and one primary school where storytelling was applied to teach German. The following paper focuses on the analysis of the applied storytelling technique and gives a detailed description of the results. Of particular importance in the case of the following study is the long-lasting effectiveness of the adopted teaching technique. The article describes how this particular teaching technique has influenced the children's attitudes towards the target language and culture. It also affords some fresh insights into the process of teaching an FL to children.
\end{abstract}

\section{Introduction}

Teaching intercultural aspects at preschool and early primary school education stages is not a key subject of the study despite some favourable conditions to do so. Children by the age of 10 are devoid of emotional prejudices, which is expressed by their openness to intercultural differences as well as readiness to accept new roles that facilitate spontaneous identification with foreign language characters. However, after reaching the critical age of 10 , this attitude dwindles when it comes to the acquisition of one's mother tongue and native enculturation processes. It results in establishing 
both language and cultural habits, and losing openness (see Doyé 1993: 54; LeopoldMudrack 1998: 40-41, 53). ${ }^{1}$ Therefore, it is vital to use, support and maintain those children's abilities which are crucial to successful foreign language learning.

In his article entitled Wozu lesen wir Geschichten im Fremdsprachenunterricht? Zur Entwicklung von Empathie-, Kooperations- und Urteilsfähigkeit, Lothar Bredella (2012: 11-12) compiled a few important theses based on the literature:

- we come to the world we did not create and in this world we must learn how to operate; stories are here to guide us;

- stories enable us to safely come to know new worlds and take actions;

- people need stories in order to understand their environment;

- it is not about understanding the characters in fairy tales but about understanding people in the real world;

- stories allow children to come into contact with people of different cultures and from different periods of time.

The above statements suggest that everyday stories and fairy tales help to create one's own cultural image of the world. If the stories and their educational roles are understood in the above sense, considerable significance should be attached to them and their contribution to the development of intercultural communication. It is because the stories told in a foreign language help to effectively expand an individual image of the world. According to Bliesener (1998: 15), intercultural teaching involves an insight into every man's inextricable bond with their own culture and their values, understanding of the target culture, recognizing it as equal to one's own culture, and also the ability to notice some common traits between them. These goals are attainable through the stories presented in a foreign language which appeal to children and engage them both emotionally and aesthetically. They allow children to recognize certain links with their everyday life, develop their empathy towards positive characters from a different world, and experience a foreign language atmosphere in which these stories are presented. The emotions that appear when listening to stories provide access to the foreign language and its culture, performing in particular its motivating function at the same time. The relations between emotions and foreign language teaching are to be proved by presenting and commenting on the results of the diagnostic study.

The aim of the applied form of teaching is to familiarize children with a foreign language by telling them moving stories. The usefulness of narrative texts in foreign language teaching results from the following facts:

1. Narrative thinking is an innate ability.

2. Narrative texts encourage children to think and behave in an empathetic way.

3. Narrative texts release positive emotions among children, which boosts the right brain hemisphere and episodic memory, and allows them to effectively use natural abilities to acquire a language. ${ }^{2}$

1 Some studies suggest the highest level of prejudice can be observed among nine-year-old children. For further information see Leopold-Mudrack (1998: 53) and Kubanek (2006: 72-74).

2 For further information see Iluk (2006). 
Another vital element of the teaching technique is the lack of compulsion to speak reproductively (imitatively) which usually occurs during traditional language courses for children where the immediate reproduction of the language material serves to revise and internalize it.

Our courses provided children with an opportunity to observe the use of the language in clear contexts for a longer period of time, accompanied by extra linguistic activities involving the connection of language learning with non-verbal activity. Movement activities correlated with the content of the stories and were meant to be clear and intelligible to children, while their performance was supposed to be enjoyable (see Piepho 2002: 20-23; Iluk 2006; Iluk 2012b; Iluk 2015b: 28-34).

\section{Aim of the study}

A series of language courses was organized in three kindergartens and one primary school where German as a foreign language was taught according to the principles of storytelling. It was a part of the study project funded by the Polish Ministry of Science and Higher Education and carried out under the auspices of the Institute of German Philology at the University of Silesia. ${ }^{3} 95$ children (65 kindergarten pupils and 30 primary school pupils) participated in the project. The courses lasted for only one semester (from February 16 until June 20, 2015) due to limited time of the project and the organization of the school and academic years. The classes were conducted by 11 postgraduate students of teaching specialization. They were aided by 5 tutors and one coordinator in the scope of methodology, preparation of the programme, visual materials and teaching.

\section{Scheme of the study}

The course was comprised of 38 lessons in each group of children. The classes were held twice a week. In the kindergarten groups, the time span was shorter due to the lower concentration level among children of that particular age. All groups were presented with 5 narrative texts altogether:

- The enormous turnip (Rübenziehen),

- The very hungry caterpillar (Die kleine Raupe Nimmersatt),

- In the dark, dark woods (In einem dunklen, dunklen Wald),

- Kim and the Little Witch (Kim und eine kleine Hexe),

- The three little pigs (Die drei kleinen Schweinchen).

These fairy tales were selected according to some definite criteria (in view of their high lexical redundancy, repetitive fragments of the text and possibilities of content animation). They were also properly adapted and simplified in terms of the

3 The complete project was published in Iluk (2015a). 
language. However, it is worth noticing that excessive simplification of the text when it comes to its level of complexity leads to counterproductivity, and, as our experience shows, children wish to be cognitively and emotionally challenged when listening to the text.

Working with every fairy-tale text took 5 lesson units. The content of the text (fairy tale) was presented by means of a puppet or suitable props. Appropriate images, including pictures, worksheets, facial expressions and gestures were helping children to guess the meaning of the utterances, new words and expressions, both in the foreign language and in their native language. Before the story was presented, the children could anticipate its content by naming or guessing the following:

- characters;

- the most essential objects and their properties;

- the most important actions;

- place, time of action and ways of performing the activities (see Iluk 2012a: 68-69).

What could be noticed when narrating the story for the second time was the children's direct involvement in the animation of the story content. Gradual involvement in narrating the story, either in the form of character animation or through repetition of permanent fragments of the text, brought them joy, which led to maintaining positive emotions and increasing their motivation and attention.

In order to establish the effectiveness of the language course, each child took tests for comprehension. The evaluation was meant to answer the following study questions:

1. Are children able to achieve relatively high and stable level of receptive skills (measured by the number of words and sentences)?

2. Do children taught with the storytelling technique understand longer utterances in a foreign language and correctly decode more complex grammatical structures?

3. Does the prolonged apperception phase (so-called incubation period) positively affect the effectiveness of language acquisition?

4. Is the teaching technique more effective than traditional teaching techniques which are based on the linear presentation of the teaching content and reproductive speaking?

5. In what way does the applied technique affect children's attitudes towards a different world and a target language?

\section{Data collection tools}

The assessment of receptive skills among children was conducted twice: the first time at the end of the course in June, and at the end of September. It was the unexpectedly good test results of the first one that spurred the latter, which had not been planned before in the study programme. The September evaluation was intended to establish a long-term effect of the storytelling technique since no such results had 
been published before. To achieve this, we used the same testing material. The first evaluation embraced 67 children, including 43 five- and six-year-olds and 24 eightand nine-year-olds. In September, 54 children (35 kindergarten pupils and 19 primary school pupils) could take part in the test. The differences between the number of test takers are the result of the fact that not all of them were present during the test. Some of them began their school education and they could not be reached after the summer holiday period.

\section{Course of the study}

The data collection tools measuring the effectiveness of teaching were supposed to arouse interest among children and ensure their satisfaction and congenial atmosphere during the test. In the first part of the test, the children were presented with a string of pictures ( 15 strings for kindergarten pupils and 18 strings for primary school pupils); each string consisted of 4 different illustrations. ${ }^{4}$ The participants were expected to assign the spoken sentences to an appropriate illustration which precisely conveyed the meaning of the sentence. ${ }^{5}$ Correct identification of the picture indicated that the sentence was understood properly. It should be pointed out that the sentences were of various length and formal structure, which required a high degree of receptive skills and concentration. The test included simple affirmative, imperative and co-ordinate clauses, and occasionally subordinate clauses.

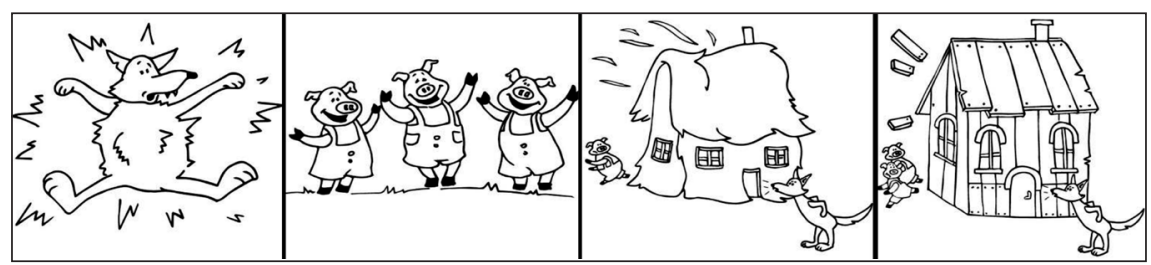

The wolf huffs, and he puffs, and he blows the house of wood down. (Der Wolf hustet und pustet und pustet das Haus aus Holz zusammen.)
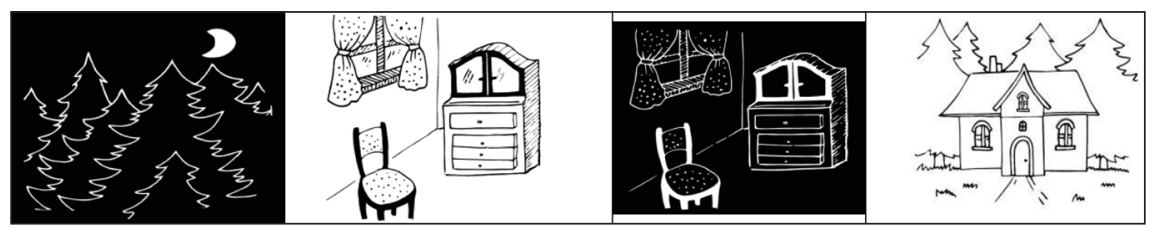

And in that dark, dark room, there is a dark, dark cupboard. (In einem dunklen, dunklen Zimmer ist ein dunkles, dunkles Schränkchen.)

4 In view of different levels of cognitive maturity among kindergarten and primary school children, the texts differed in terms of length and language input. It involved three more sequences of pictures that primary school children were given during the test.

5 All of the illustrations that appear in the article have been used by kind permission of the author who also performed her role of a tutor in the study. They come from Gładysz (2015). 


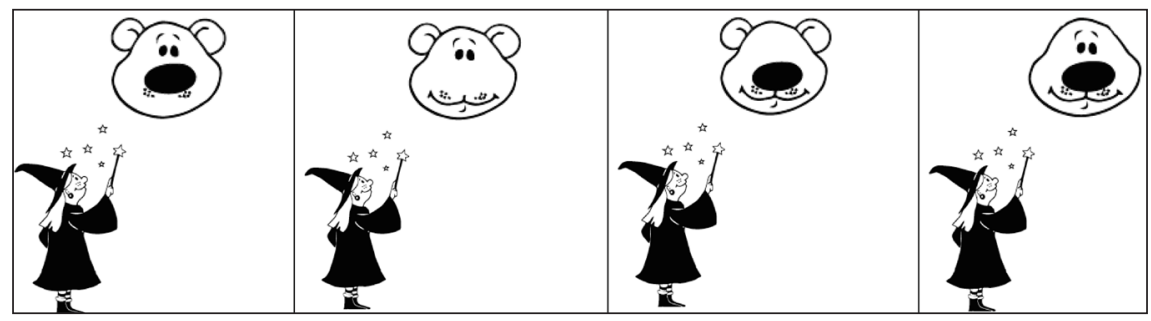

Abracadabra, hey, hey, hey, now I wish your eyes away! (Abrakadabra, hey, hey, hey, und jetzt sind deine Augen weg!)

Picture 1. Examples of sentences from the first part of the test: proper picture identification

In the second part of the test, the children were asked to respond to requests and instructions to the activities given by the teacher, or to mime them. This particular form was chosen to make them unaware of the fact that they were being tested, and also to check their comprehension of typical instructions.

\begin{tabular}{|c|c|c|}
\hline \multirow{2}{*}{$\begin{array}{l}\text { Take the card with the } \\
\text { picture of an onion! } \\
\text { (Nimm das Kärtchen mit } \\
\text { einer Zwiebel!) }\end{array}$} & \multirow{2}{*}{$\begin{array}{l}\text { Point at the card with the } \\
\text { three potatoes! } \\
\text { (Zeig mir das Kärtchen mit } \\
\text { drei Kartoffeln!) }\end{array}$} & $\begin{array}{l}\text { Point at your ears! } \\
\text { (Zeig auf deine Ohren!) }\end{array}$ \\
\hline & & $\begin{array}{l}\text { Point at something red! } \\
\text { (Zeig auf etwas, was rot ist!) }\end{array}$ \\
\hline $\begin{array}{l}\text { Laugh out loud! } \\
\text { (Lache laut!) }\end{array}$ & $\begin{array}{l}\text { Sit on the carpet! } \\
\text { (Setz dich auf den Teppich!) }\end{array}$ & $\begin{array}{l}\text { Run towards the wardrobe! } \\
\text { (Lauf zum Schrank!) }\end{array}$ \\
\hline \multirow{2}{*}{$\begin{array}{l}\text { Jump on one leg towards } \\
\text { the door! } \\
\text { (Spring auf einem Bein } \\
\text { zur Tür!) }\end{array}$} & $\begin{array}{l}\text { Come to the CD player! } \\
\text { (Geh zum CD-Player!) }\end{array}$ & $\begin{array}{l}\text { Wave your hand! } \\
\text { (Winke mit deiner Hand!) }\end{array}$ \\
\hline & $\begin{array}{l}\text { Point at your nose! } \\
\text { (Zeig auf deine Nase!) }\end{array}$ & \multirow[t]{3}{*}{$\begin{array}{l}\text { Close your eyes! } \\
\text { (Mach deine Augen zu!) }\end{array}$} \\
\hline $\begin{array}{l}\text { Sit on the chair! } \\
\text { (Setz dich auf einen Stuhl!) }\end{array}$ & $\begin{array}{l}\text { Turn around! } \\
\text { (Dreh dich um!) }\end{array}$ & \\
\hline $\begin{array}{l}\text { Clap your hands! } \\
\text { (Klatsch in deine Hände!) }\end{array}$ & & \\
\hline
\end{tabular}

Table 1. Examples of sentences from the second part of the test: responding to a request or instruction

Another part of the test required children to match the sentence they had just heard to the right picture. The true/false statements were in the form of riddles. The children were willing to take part in such activities as they required concentration and cleverness.

The caterpillar eats through four strawberries.

(Die Raupe frisst sich durch vier Erdbeeren.)

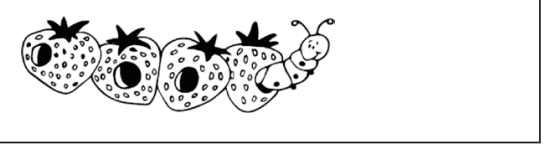




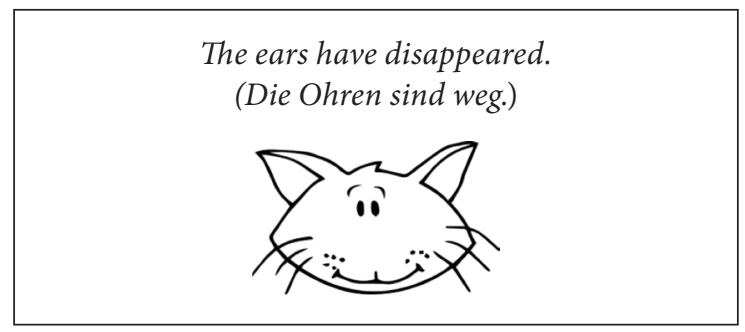

The three pigs build a house of straw. (Die drei Schweinchen bauen ein Haus aus Stroh.)

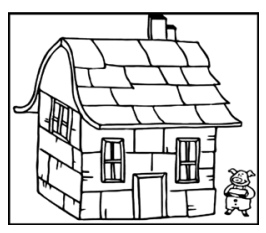

Picture 2. Examples of sentences from the third part of the test: true/false statements

The testing material contained 122 lexical items in all, including 46 nouns, 32 verbs, 19 adjectives, adverbs and numerals, 15 prepositional phrases (in the form of adverbials of place), 7 prepositions, 2 pronouns and 1 negation. The above items are listed in Table 2 (see Wowro 2015: 83-84).

The table clearly shows that the children were presented not only with the great number of vocabulary items but also the vocabulary that was formally and semantically varied. It included both regular and irregular verbs, separable and inseparable verbs, reflexive and impersonal verbs as well as qualitative and relative adjectives which provide more varied description of objects, people and their actions. Owing to a relatively large number of verbs, the children could become acquainted with the language not only in elementary speech acts that name people, objects and their features, but also in various interactions of everyday life which prove to be significant in terms of communication. ${ }^{6}$

Extensive language material and language immersion leave the learner with a short impression of being totally immersed in a foreign language, which motivates the learner to think about his own process of comprehension. In that way, the learner arrives at a conclusion that his knowledge of the world, combined with the language means and teaching aids, is sufficient to decode the message in a foreign language (Kubanek-German 1993: 52).

6 The study conducted by Nauwerck (2012: 121) reveals that performing speech acts to name the themes of pictures or facts (e.g. What is this? It's a dog.) does not develop communicative competence in the long run. 


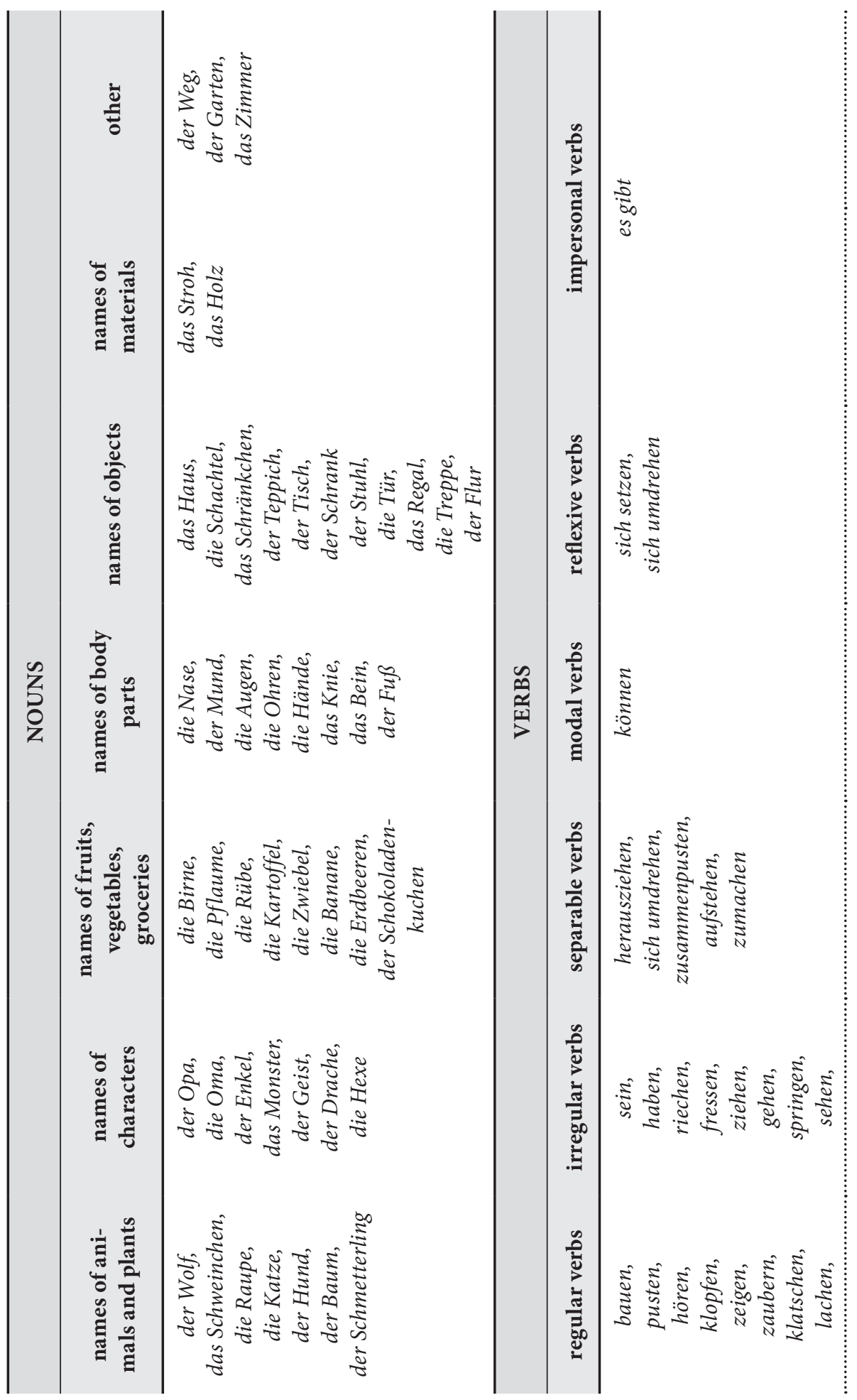




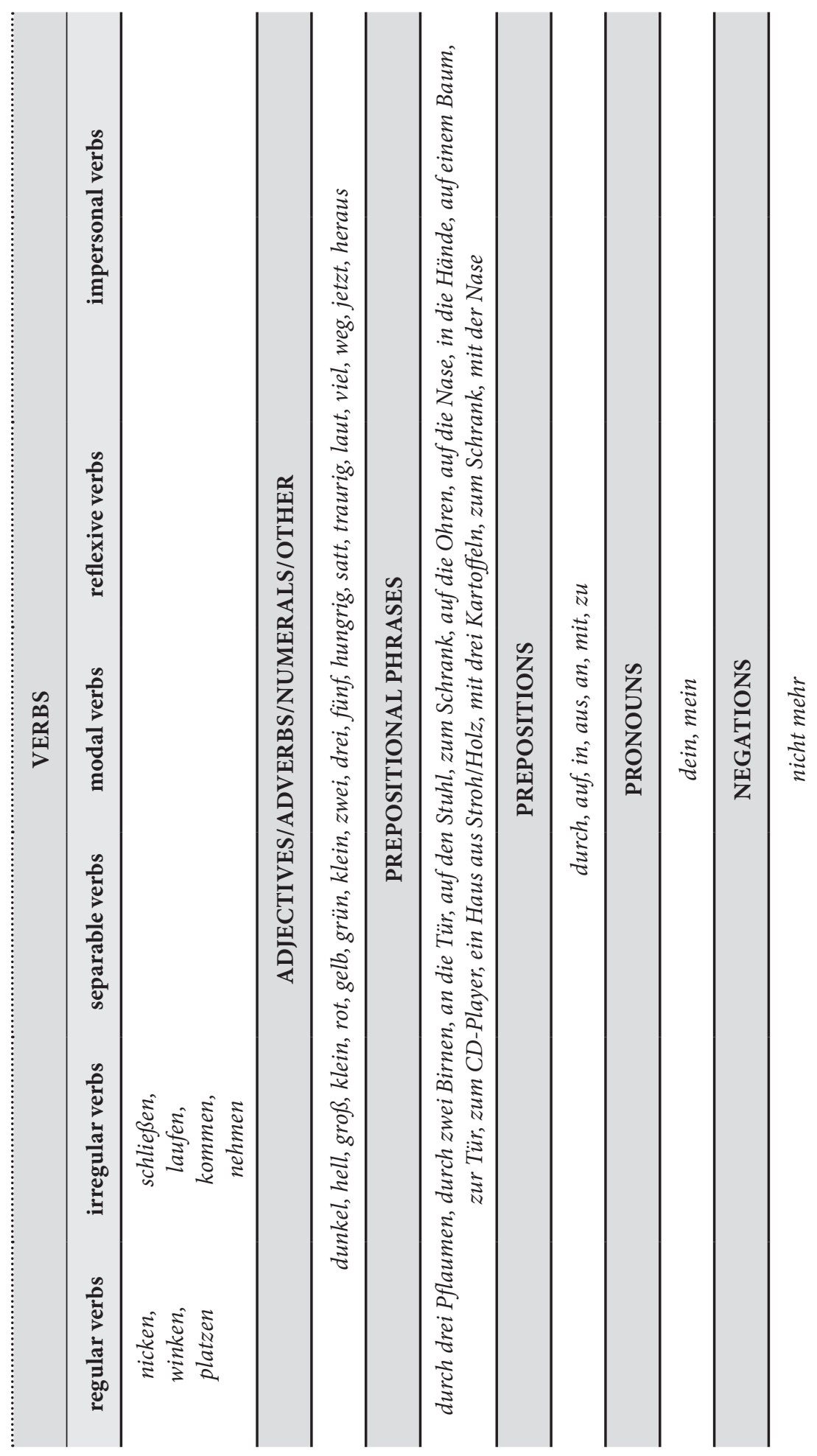

है 


\section{Presentation of study results}

Further in the article, we intend to present and analyze the results achieved by kindergarten and primary school children in both tests that measured the effectiveness of the use of storytelling.

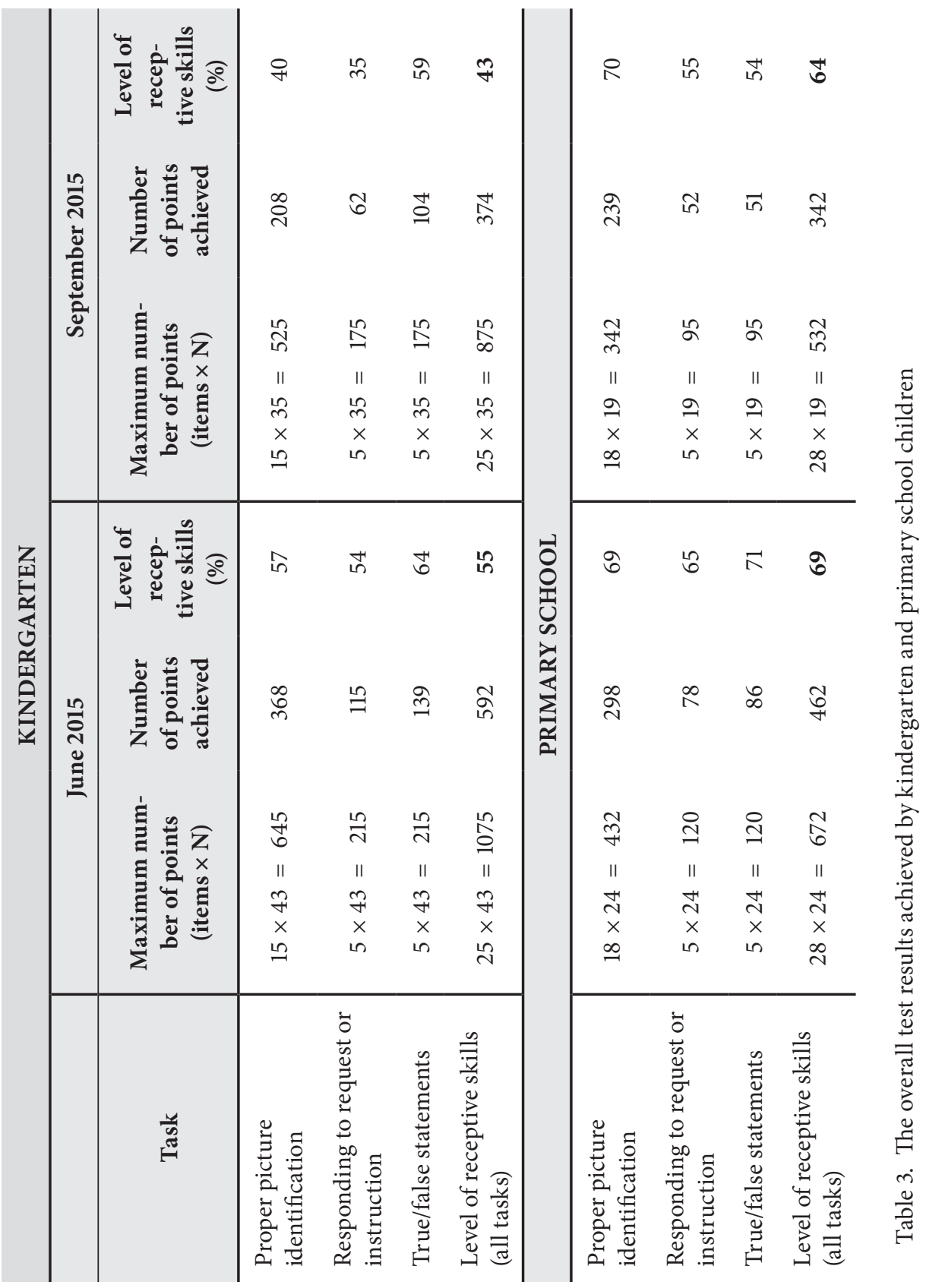


The results obtained are shown in the following bar charts:

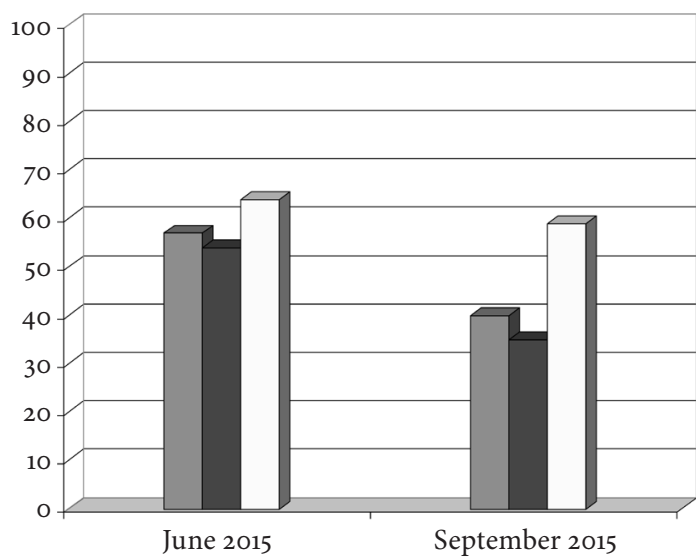

$\square$ Proper picture

identification

$\square$ Responding to request

or instruction

$\square$ True/false statements

Figure 1. Results obtained in kindergarten in June and September 2015

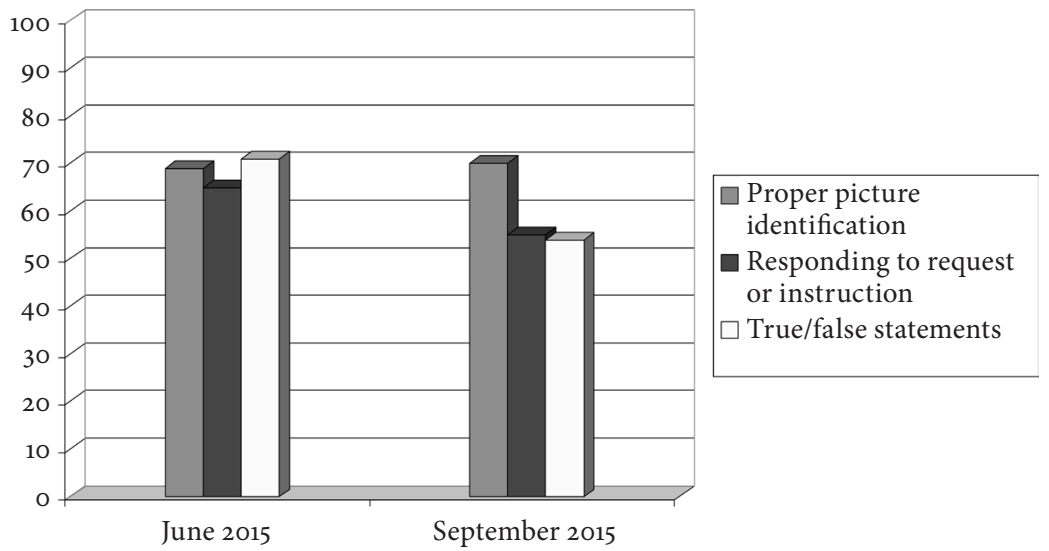

Figure 2. Results obtained in primary school in June and September 2015

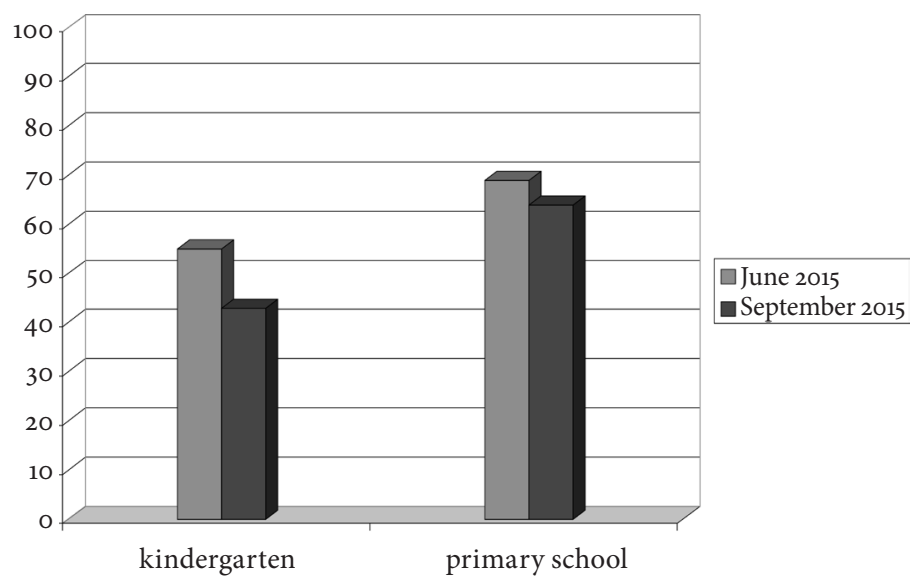

Figure 3. Comparison of receptive skills among kindergarten and primary schools children 
The results obtained in both groups confirm high effectiveness of the applied teaching technique in teaching and learning. The kindergarten pupils correctly performed the test tasks in June and September, achieving an average result of $55 \%$ and $43 \%$ respectively, whereas the primary school children averaged out at $69 \%$ and $64 \%$ respectively in terms of receptive skills. The test repeated three months later confirmed the longlasting effect of the applied teaching technique. High effectiveness of the receptive skills (listening comprehension) results from the fact that the language material (input) was delivered, taught and revised in meaningful and motivating contexts.

\section{Interpretation of study results}

The content presented to the children proved interesting and essential, which facilitated more detailed processing of information without unnecessary cognitive effort. Language learning was firmly tied with movement activities which contribute to the increase of concentration and have a positive influence on language processing (see Ratey, Hagerman 2009: 99). ${ }^{7}$ High effectiveness of learning creates a realistic opportunity to achieve sufficient scope of lexical items or linguistic experience in a short period of time, which is indispensable for further, faster and more effective process of language acquisition (see Bleyhl 2000: 16; Iluk 2012b: 156).

Gradual forgetting is the reason for slightly smaller percentage value within the receptive skills, measured after the three months when the children were not exposed to the language. Deviations in the results between the two groups can be explained on the basis of visible differences within their cognitive maturity, memory capacity and other factors. It is worth mentioning that the long-term memory of younger children is only at the initial phase of development.

Surprisingly, the number of corrected responses to requests or instructions fell by $10 \%-20 \%$ in comparison to those measured in June. A similar tendency can be observed with true/false statements. It probably may be explained by the fact that the language input during the course was insufficiently automated. Specific reasons for the lowered level of receptive skills within this scope require further attention and studies.

The evaluation did not take into account the knowledge of single words or isolated expressions but the comprehension of longer content-rich utterances. The test confirmed that the children were able to understand correctly sentences containing up to 12 words. They found no difficulty in recognizing the appropriate meaning of complex syntactic structures and implicit logical relations. They were able to process cognitively simple and complex syntactic structures of a different number of actants. A similar phenomenon could not be observed among other control groups that were taught as part of another study according to traditional

Experimental study by Hille et al. (2010: 337) reveals that pupils who combined learning vocabulary and movement activities simultaneously were able to recall on average 15 out of 20 words after a period of 13 weeks, whereas the pupils from the control group recalled only 5 words. 
grammatical and lexical progression. In this case, learning more complex syntactic structures was impossible due to arbitrarily accepted grammatical progression (see Iluk 2012b: 157).

The results support the positive influence of a prolonged receptive phase on the effectiveness of language acquisition. On the one hand, it creates a sound basis for longer texts which serve better development of comprehension and production. On the other hand, the incubation period enables children to concentrate fully on the content, production, and immediate verification of their own hypotheses referring to the meaning of particular words, sentences and the content of a text. The applied teaching technique helped to take advantage of children's innate receptive skills (see Leopold-Mudrack 1998: 121; Iluk 2012a: 65; Iluk 2012b: 157). Another advantage of the technique is the lack of obligation to produce loud imitation (silent period), which allows pupils to set their own pace of learning (see Leopold-Mudrack 1998: 125). The lack of pressure, which would be the result of necessary and immediate reproduction of yet insufficiently internalized foreign structures, had a positive effect on children's readiness to recognize individually the sense of heard utterances as well as on their long-term remembering. This comfort of learning does not exist in so-called traditional early school foreign language teaching. Iluk (2008: 55-56) could state when conducting different experiments that any attempts to force children to speak in a foreign language from the very first lesson ended in failure. Moreover, the children were rapidly losing their interest in not only reproductive (imitative) speaking exercises but the language learning itself. The reasons for a lowered level of motivation to acquire a language lie in them being cognitively overburdened when developing their listening and speaking skills at the initial stage of learning, which is clearly visible by their lowered level of concentration and sensitivity to any distractors (see Iluk 2012a: 73-74). Such problems were not encountered, or at least to a slight degree, among children taught by storytelling.

Even though developing speaking skills and its evaluation were not a target on our courses, some first signs of spontaneous spoken production might have been observed. Productive speaking examples were registered by means of an evaluation sheet. It included the following information: greetings and farewells, introducing oneself, understanding the teacher and following their instructions, naming the toys, colours, singing, animating the stories, recognizing and using the topic vocabulary, apologizing, expressing emotions. The evaluation also embraced children's emotional behaviours towards didactic activities. Table 4 clearly illustrates the children's reactions to the language input (see Wowro 2015: 88).

\begin{tabular}{c|ccccc}
\multirow{2}{*}{ Type of skill } & \multicolumn{4}{|c}{ Reached level } \\
\cline { 2 - 5 } & excellent & very good & good & poor & very poor \\
\hline Greetings and farewells & \multicolumn{4}{|c}{} \\
Introducing oneself & & & & \\
\hline
\end{tabular}




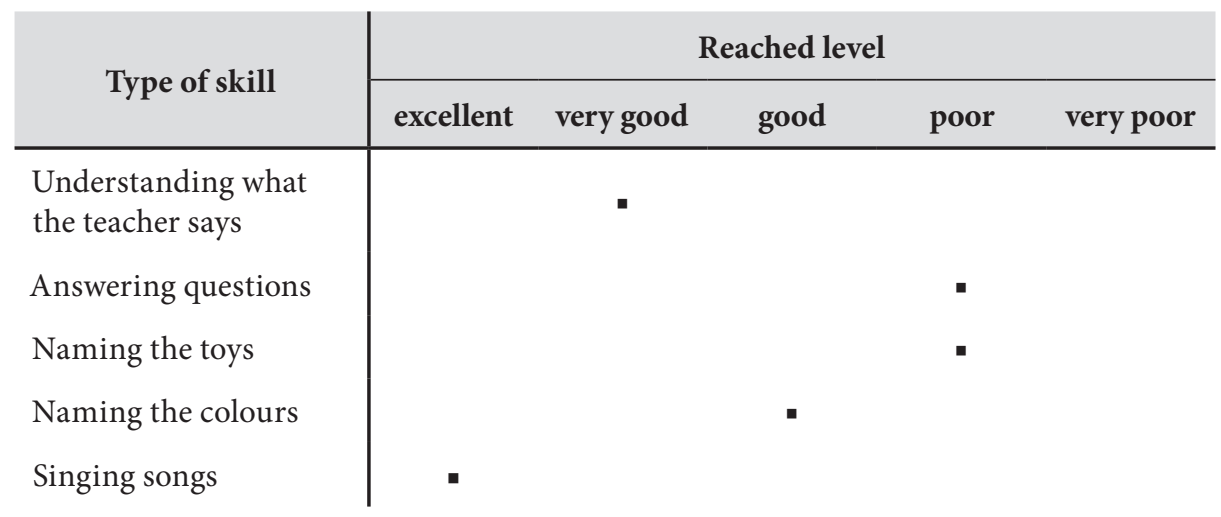

Table 4. The evaluation of skills among kindergarten and primary school pupils

The table indicates that despite the respected silent period, it was specifically the forms of reproductive (imitative) language behaviour that developed within those spheres which were frequently present in typical lesson situations and, therefore, were sufficiently practiced. With the growing level of comprehension, the children spontaneously joined the narration and admitted taking great joy in spontaneous participation through repetition of fixed text fragments.

The findings point to the conclusion that storytelling constitutes a specially effective teaching technique. Unlike in the case of the traditional forms, which are based on very limited language input and intensive imitation, the teaching techniques in the adopted forms create even more favourable conditions for the activation of innate processes of language acquisition. It also allows for more cognitive development of children. As Iluk (2012b: 157) puts it, the more favourable conditions for language learning are ensured by the following benefits of storytelling which:

- exposes children to more interesting and content-rich teaching material which contains a wide range of vocabulary;

- presents the language material in meaningful and compelling contexts;

- enables listening to and guessing new vocabulary in clear situations;

- enables holistic (intuitive) registering of the new language content, i.e. firstly children are taught to understand the information and intentions they have heard and not single vocabulary items or grammatical structures;

- develops logical thinking among children through the interpretation of series of events or the cause-and-effect relationship;

- boosts both hemispheres as well as both systems of remembering (declarative: for new vocabulary, and procedural: for events, routine behaviours and emotional experiences);

- enables categorizing the input into already internalized knowledge on the basis of hypotheses; information is ordered as a whole, which enables deeper and more lasting input processing;

- creates authentic instances of communication appreciated by children; 
- releases positive emotions and triggers real joy of learning, which raises the level of motivation and attention, facilitates remembering and develops creativity;

- allows for a prolonged receptive period in which children are given a real opportunity to focus on the content, formulate and verify hypothesis, and guess;

- through the reduced pace of speaking, the way of speaking (intonation, rhythm), and the clear division of words and syllables, it creates better conditions for mental processing of unknown sounds, patterns and language rules, which results in more correct pronunciation, intonation or grammatical forms of utterances;

- contributes to rapid learning progress and real success in learning, which in turn encourages noticeable growth of inner motivation among children.

\section{Conclusions}

The study proved that it is possible to pursue intercultural goals thanks to openness to the world, so typical of children. All the children revealed clearly positive attitudes towards the foreign language and culture. Foreign language classes which are run in a pleasant atmosphere and create conditions to achieve success in learning, but also enable regular participation in the culture of the taught language through storytelling, lead to constant readiness to continue foreign language learning. It is supported by those children who expressed their willingness to learn the same language the following year, which is an exception in the case of traditionally run language classes during which pupils frequently become easily bored and find classes monotonous. Children's requests were approached seriously by the authorities of one of the kindergartens who decided to, despite the common predominance of the English language, introduce regular German classes taught according to the principles of storytelling, starting from the following school year.

\section{References}

Bleyhl W. (ed.). 2000. Fremdsprachen in der Grundschule. Geschichten erzählen im Anfangsunterricht. Storytelling. Hannover.

Bliesener U. 1998. Warum Frühbeginn? - Bliesener U., Edelenbos P. (eds.). Früher Fremdsprachenunterricht: Begründungen und Praxis. Leipzig: 8-19.

Bredella L. 2012. Wozu lesen wir Geschichten im Fremdsprachenunterricht? Zur Entwicklung von Empathie-, Kooperations- und Urteilsfähigkeit. - Zeitschrift für Fremdsprachenforschung 23.1: 3-31.

Doyé P. 1993. Fremdsprachenerziehung in der Grundschule. - Zeitschrift für Fremdsprachenforschung 4.1: 48-90.

Gładysz J. (in cooperation with K. Sowa). 2015. Erzählen von Geschichten. Bajki i opowiadania do nauki języka niemieckiego dla dzieci w wieku przedszkolnym i szkolnym. Żory.

Hille K. et al. 2010. Szenisches Lernen im Fremdsprachenunterricht - die Evaluation eines Schulversuchs. - Diskurs Kindheits- und Jugendforschung 5.3: 337-350.

Iluk J. 2006. Jak uczyć małe dzieci języków obcych? Częstochowa.

Iluk J. 2008. Teoria i praktyka w nauczaniu języków obcych w przedszkolu. - Języki Obce w Szkole 4: 48-59. 
Iluk J. 2012a. Praktische Anweisungen zum narrativen Ansatz im fremdsprachlichen Frühunterricht. -Bujňáková M., Paračková J., Irsfeld Ch. (eds.). Deutsch in Forschung und Lehre. Teil I, Sammelband, X. Tagung des Verbandes der Deutschlehrer und Germanisten der Slowakei (1.-4. September 2010, Prešov). Prešov: 65-75.

Iluk J. 2012b. Der narrative Ansatz und dessen Effizienz im Kindergarten und im Primarbereich. - Deutsch als Fremdsprache 49.3: 150-159.

Iluk J. (ed.). 2015a. Nauczanie języków obcych w przedszkolu i na etapie wczesnoszkolnym na przykładzie języka niemieckiego. Katowice.

Iluk J. 2015b. Przygotowanie dzieci do posługiwania się językiem obcym w kontekście nowego rozporządzenia Ministerstwa Edukacji Narodowej. - Iluk J. (ed.). Nauczanie języków obcych w przedszkolu i na etapie wczesnoszkolnym na przykładzie języka niemieckiego. Katowice: 15-36.

Kubanek A. 2006. Die wichtigsten pädagogischen Grundsätze für die fremdsprachliche Früherziehung. Forschungsveröffentlichungen, gute Praxis \& zentrale Prinzipien. Endbericht der Studie EAC 89/04 (Lot 1). [available at: http://ec.europa.eu/geninfo/query/index.do? queryText=Die+wichtigsten $+\mathrm{p} \% \mathrm{C} 3 \%$ A4dagogischen+Grunds\%C3\%A4tze+\&summary= summary\&more_options_source=global\&more_options_date $=*$ \&more_options_date_ from $=\&$ more_options_date_to $=\&$ more_options_language $=$ de $\&$ more_options_f formats $={ }^{*} \&$ swlang $=$ de].

Kubanek-German A. 1993. Zur möglichen Rolle des Narrativen im Fremdsprachenunterricht für Kinder. - Primar: Zeitschrift für Deutsch als Fremdsprache im Primarbereich 3: 48-54.

Leopold-Mudrack A. 1998. Fremdsprachenerziehung in der Primarstufe: Voraussetzungen, Konzept, Realisierung. Münster, New York, München, Berlin.

Nauwerck P. 2012. Zweisprachigkeit im Kindergarten. Konzepte und Bedingungen für das Gelingen. Stuttgart.

Piepho H.-E. 2002. Stories' ways. - Bleyhl W. (ed.). Fremdsprachen in der Grundschule. Geschichten erzählen im Anfangsunterricht. Storytelling. Hannover: 20-34.

Ratey J., Hagerman E. 2009. Superfaktor Bewegung. Kirchzarten bei Freiburg.

Wowro I. 2015. Pomiar efektywności i ewaluacja wyników nauczania języka niemieckiego metodą narracyjną w przedszkolach i szkole podstawowej. - Iluk J. (ed.). Nauczanie języków obcych w przedszkolu i na etapie wczesnoszkolnym na przykładzie języka niemieckiego. Katowice: 67-94. 